\title{
Development of a Tier-1 Assay for Assessing the Toxicity of Insecticidal Substances Against Coleomegilla maculata
}

\author{
YUNHE LI, ${ }^{1,6}$ JARED OSTREM, ${ }^{2}$ JÖRG ROMEIS, ${ }^{3}$ MAO CHEN,${ }^{1}$ XIAOXIA LIU, ${ }^{1}$ \\ RICHARD L. HELLMICH, ${ }^{4}$ ANTHONY M. SHELTON, ${ }^{1,5}$ AND YUFA PENG ${ }^{6}$
}

Environ. Entomol. 40(2): 496-502 (2011); DOI: 10.1603/EN10248

\begin{abstract}
To assess the potential dietary effects of insecticidal substances on the predacious ladybird beetle, Coleomegilla maculata De Geer, a Tier-1 laboratory testing system was developed. Artificial diets using shrimp eggs were developed, and a tier-1 bioassay examining C. maculata development and survival was designed based on those diets. To further measure the artificial diet in a Tier-1 testing system, larvae of C. maculata were fed the diet treated with different concentrations of an inorganic stomach poison, potassium arsenate (PA), or a cysteine protease inhibitor, E-64. The results demonstrated that the testing system was capable of detecting the dietary effects of both substances on the survival and development of C. maculata. With increasing concentrations of PA in the diet, fewer larvae developed to adults, with only $22.7 \%$ larvae surviving to the adult stage in the treatment with the highest content of PA (32 $\mu \mathrm{g} / \mathrm{g}$ of diet). Likewise, dose-dependent responses also were found for other life-table parameters of C. maculata. Similar to the assays with PA, the survival rates of C. maculata consistently decreased with increasing E-64 content in the diet. Survival analysis showed that the insects fed E-64 at 50,150, and $450 \mu \mathrm{g} / \mathrm{g}$ in the diet had significantly lower survival rates compared with those on the untreated artificial diet. The study presented here describes a robust testing system that will be useful for assessing the potential hazard (or toxicity) effects after dietary exposure of insecticidal compounds produced by GE plants or conventional insecticides on the ladybird predator, C. maculata.
\end{abstract}

KEY WORDS environmental risk assessment, potassium arsenate, E-64, nontarget effects, tiered testing

Several widely planted crops have been genetically engineered (GE) to express genes encoding traits to protect them against insect pests, herbicides, and plant pathogens. To date, the only commercialized GM crops that are protected against insect pests are maize (Zea mays L.) and cotton (Gossypium spp.) and both express genes encoding for insecticidal crystalline (Cry) proteins derived from the soil bacterium, $B a$ cillius thuringiensis Berliner (so called Bt crops). Since the first $B t$ crops were planted commercially in 1996, $B t$-transgenic varieties have been rapidly adopted worldwide as a result of economic benefits to growers and have led to a significant reduction of the use of conventional insecticides under some circumstances

\footnotetext{
${ }^{1}$ Department of Entomology, Cornell University/NYSAES, 630 West North Street, Geneva, New York 11456.

2 Product Safety Assessment, Pioneer Hi-Bred International, Inc., DuPont Agricultural Biotechnology, Ankeny, IA. 50021.

${ }^{3}$ Agroscope Reckenholz-Tänikon Research Station ART, 191 Reckenholzstrasse, Zurich 8046, Switzerland.

${ }^{4}$ U.S. Department of Agriculture-Agricultural Research Service (USDA-ARS), Corn Insects and Crop Genetics Research Unit, and Department of Entomology, Iowa State University, Ames, IA 50011.

${ }^{5}$ Corresponding author, e-mail: ams5@cornell.edu.

${ }^{6}$ State Key Laboratory of Plant Disease and Insect Pests. Institute of Plant Protection, Chinese Academy of Agricultural Science, Beijing 100193, China.
}

(Fitt 2008, Brookes and Barfoot 2010). In 2009, insectresistant genetically engineered (IRGE) crops were grown on 50.4 million ha in 25 countries (James 2009).

As with any new technology questions about the potential risks have arisen, such as the possible impact of GE plants on the environment (NAS 2002). The concerns regarding the environmental impact of $\mathrm{GE}$ plants include those worries related to their possible invasiveness in ecosystems (Snow et al. 2005); outcrossing and horizontal gene transfer (Yao et al. 2008, Rong et al. 2010); development of resistant pest populations that would again require the input of pesticides (Tabashnik et al. 2009); and effects on nontarget organisms (NTOs). In the case of IRGE plants, effects on NTOs is a particular concern, as these organisms provide important ecosystem services such as biological control (predators and parasitoids), pollination, and decomposition (Kennedy 2008, Romeis et al. 2008a).

For assessing the effects of IRGE crops on nontarget organisms (NTOs), a tiered assessment procedure has been recommended and widely accepted by environmental risk assessors and regulatory agencies (U.S. EPA 1998, Garcia-Alonso et al. 2006, Rose 2007, Romeis et al. 2008b, Duan et al. 2010). One important step in this procedure is to determine the potential 
hazard or toxicity of the insecticidal compound produced by GE plants, such as a Cry protein, to selected test species. Such effects or toxicity tests are typically conducted in the laboratory and referred to as Tier-1 studies. In these tests, surrogate NTOs representing particular taxonomic or functional guilds can be exposed to insecticidal proteins under exposure conditions that exceed the level of exposure in the field (Dutton et al. 2003, Raybould 2007, Romeis et al. $2008 \mathrm{~b}, 2010)$. Based on characteristics of the toxin, a dietary exposure assay may be required in which the test substances (i.e., the insecticidal protein) can be incorporated into a diet substrate at a high dose. For example, various Cry proteins have been tested for toxicity assessment against several groups of NTOs (OECD 2007). Recently, a meta-analyses comparing results of nontarget arthropods exposed to Cry proteins in laboratory studies with results derived from independent field studies suggested that laboratory studies of transgenic insecticidal crops show effects that are either consistent with, or more conservative than, those results found in the field (Duan et al. 2010).

The ladybird beetle, Coleomegilla maculata De Geer (Coleoptera: Coccinellidae) is a common and abundant predator found in many cropping systems throughout many regions of the world (CABI 2007). Both larvae and adults of C. maculata are predaceous, feeding on aphids, thrips, and lepidopteran eggs and larvae (Hoffmann and Frodsham 1993, Duan et al. 2002), Lundgren et al. 2002. In addition to prey, $C$. maculata may also feed on various fungi or plant tissues, such as seedling, pollen, sap, and nectar as alternative food sources (Pemberton and Vandenberg 1993; Duan et al. 2002; Lundgren and Wiedenmann 2002, 2004; Moser et al. 2008). Therefore, this species is likely exposed to Cry proteins in $B t$ crops directly through pollen feeding. This together with the fact that the species can be easily reared and tested in the laboratory makes it a good surrogate for the assessment of nontarget effects of IRGE crops (Pilcher et al. 2005, Riddick et al. 1998, Duan et al. 2002, Lundgren et al. 2002). Limitations of working with this species are, however, the lack of an appropriate artificial diet in which test proteins can be easily incorporated in high concentrations. Most previous studies with Bt crops have used GE plant pollen as the test substance.

This study was designed to aid in the development of a system that could be used for measuring possible effects of insecticidal compounds produced by GE plants using the coleopteran predator, C. maculata. The first objective was to develop effective and efficient artificial diets that allow for normal development and reproduction of C. maculata. A second objective was to develop a Tier-1 laboratory testing system using an artificial diet in which C. maculata could be exposed to known and high doses of organic and inorganic compounds to determine their effects on the survival and development of C. maculata.
Table 1. Components of shrimp egg-based artificial diets used to rear $C$. maculata

\begin{tabular}{|c|c|c|c|c|}
\hline No. & Ingredient & Diet 1 & Diet 2 & Diet 3 \\
\hline 1 & Shrimp eggs & $\begin{array}{l}182 \mathrm{~g} \\
\quad \text { (intact) }\end{array}$ & $\begin{array}{l}182 \mathrm{~g} \\
\quad \text { (ground) }\end{array}$ & $\begin{array}{l}182 \mathrm{~g} \\
\quad \text { (ground) }\end{array}$ \\
\hline 2 & USDA vitamin $\operatorname{remix}^{a}$ & $0 \mathrm{~g}$ & $5 \mathrm{~g}$ & $0 \mathrm{~g}$ \\
\hline 3 & Methyl paraben & $0 \mathrm{~g}$ & $1 \mathrm{~g}$ & $1 \mathrm{~g}$ \\
\hline 4 & Sorbic acid & $0 \mathrm{~g}$ & $2 \mathrm{~g}$ & $2 \mathrm{~g}$ \\
\hline 5 & Agar & $0 \mathrm{~g}$ & $10 \mathrm{~g}$ & $15 \mathrm{~g}$ \\
\hline 6 & Distilled $\mathrm{H}_{2} \mathrm{O}$ & $0 \mathrm{~g}$ & $800 \mathrm{ml}$ & $800 \mathrm{ml}$ \\
\hline
\end{tabular}

${ }^{a}$ Purchased from Bio-Serve with the product number 6265 (see details on (http://www.insectrearing.com/products/vitandmin.html).

\section{Materials and Methods}

Insect. Larvae of C. maculata were obtained from a long-term laboratory colony that originated from $\mathrm{Pi}$ oneer Hi-Bred International, Inc. (Johnston, IA). The insects were maintained in a climatic chamber at $27 \pm$ $1{ }^{\circ} \mathrm{C}, 65 \pm 5 \% \mathrm{RH}$, and a photoperiod of 16:8 (L:D) h at Cornell University's Department of Entomology at Geneva, NY. Both larvae and adults were reared on lyophilized decapsulated eggs of brine shrimp Artemia franciscana (Brine Shrimp Direct, Ogden UT) and a solidified 1\% agar solution provided separately as a water source, a technique which Pioneer has used as a diet for C. maculata (Yunhi Li, unpublished data). All larvae used in the study described herein were freshly hatched (i.e., <24-h old).

Diets. Three diets were tested, with diet 1 (developed by Pioneer Hi-Bred) serving as the foundation for diets 2 and 3. The ingredients of the three diets are shown in Table 1. Diet 1 consists solely of brine shrimp eggs, with a separate agar-based water source. Diets 2 and 3 were prepared according to the following procedure: i) lyophilized shrimp eggs were ground into a fine powder using a mortar and pestle; ii) water and agar were combined and brought to a full boil, then allowed to cool for $\approx 5-10 \mathrm{~m}$ at room temperature; iii) ingredients 1-5 were mixed thoroughly in a glass cup (Table 1$)$; iv) agar solution $\left(\approx 50^{\circ} \mathrm{C}\right)$ was added to the cup and thoroughly mixed with the ingredients; v) the mixture was immediately poured into a container and left to cool and solidity. The diet was stored at $4^{\circ} \mathrm{C}$, and used within $14 \mathrm{~d}$.

Fitness of C. maculata Feeding on Artificial Diets. To measure the effectiveness of the diets in sustaining normal survival and development of C. maculata, a fitness bioassay was conducted with the three aforementioned diets. For diet 1, decapsulated shrimp eggs were poured into $30-\mathrm{ml}$ plastic cups with ventilated lids. A $1.5 \mathrm{ml}$ centrifuge tube containing solidified $1 \%$ agar/water was added to serve as the water source. For diets 2 and 3 , small cubes $\left(\approx 0.15 \mathrm{~cm}^{3}\right)$ of the respective diets were individually placed into the plastic cups. A water-saturated cotton ball was provided on the bottom of each cup to increase humidity and also served as a source of water for the test insects in all treatments. In each diet treatment, 22 neonate $C$. maculata randomly selected from progenies produced by at least 20 females were individually reared in the plastic cups. All the diets were replaced every $2 \mathrm{~d}$. The 
Table 2. Life-table parameters (means) of $C$. maculata fed one of three different shrimp egg-based artificial diets

\begin{tabular}{|c|c|c|c|c|c|c|}
\hline \multirow[t]{2}{*}{ Treatment } & \multirow{2}{*}{$\begin{array}{c}\text { Percent larvae } \\
\text { developed to } \\
\text { adults }(\%)^{a}\end{array}$} & \multirow{2}{*}{$\begin{array}{l}\text { Days to } \\
\text { pupation } \\
( \pm \mathrm{SE})^{b}\end{array}$} & \multirow{2}{*}{$\begin{array}{l}\text { Days to adult } \\
\text { emergence } \\
\quad( \pm \mathrm{SE})^{b}\end{array}$} & \multirow{2}{*}{$\begin{array}{l}\text { Weight of larva } \\
\text { after } 7 \mathrm{~d} \\
(\mathrm{mg} \pm \mathrm{SE})^{c}\end{array}$} & \multicolumn{2}{|c|}{$\begin{array}{c}\text { Newly emerged adult wt } \\
(\mathrm{mg} \pm \mathrm{SE})^{\mathrm{c}}\end{array}$} \\
\hline & & & & & Female & Male \\
\hline Diet 1 & $81.0 \mathrm{a}$ & $12.9 \pm 0.16 \mathrm{a}$ & $15.8 \pm 0.21 \mathrm{a}$ & $4.1 \pm 0.12 \mathrm{a}$ & $12.2 \pm 0.49 \mathrm{a}$ & $10.3 \pm 0.32 \mathrm{a}$ \\
\hline Diet 2 & $95.5 \mathrm{a}$ & $12.0 \pm 0.13 \mathrm{a}$ & $15.4 \pm 0.12 \mathrm{a}$ & $5.5 \pm 0.16 \mathrm{~b}$ & $13.4 \pm 0.49 \mathrm{a}$ & $11.6 \pm 0.29 \mathrm{a}$ \\
\hline Diet 3 & $95.5 \mathrm{a}$ & $12.2 \pm 0.19 a$ & $15.7 \pm 0.18 \mathrm{a}$ & $5.1 \pm 0.18 \mathrm{~b}$ & $12.3 \pm 0.55 \mathrm{a}$ & $11.4 \pm 0.40 \mathrm{a}$ \\
\hline
\end{tabular}

Means followed by the same letter in the same column are not significantly different at the 0.05 error level. Twenty-two insects were tested for each diet treatment.

${ }^{a} \chi^{2}$ test.

${ }^{b}$ Kruskal-Wallis ANOVA.

${ }^{c}$ One-way ANOVA followed by Tukey HSD when significant difference was detected.

development and mortality were recorded daily. Additionally, the larvae were weighed after $7 \mathrm{~d}$ of feeding. Once surviving adults emerged, they were sexed and weighed (within $12 \mathrm{~h}$ ).

Bioassay With Potassium Arsenate and E-64. The fitness bioassay showed that all three diets were sufficient for sustaining the survival and development of C. maculata and they were all considered to be acceptable for dietary bioassay, although 7-d larval weight was significantly higher in diets 2 and 3 compared with that in diet 1 (see results). Diet 2 was selected for the bioassay with the following reasons: 1 ) the test material was more readily incorporated into diets 2 and 3 because of their pourability, and 2) insects on diet 2 had a shorter development time to pupation and to adult, and the larvae and adults were slightly heavier compared with those insects fed diet 3 , although no statistical difference was detected (see results).

An inorganic compound potassium arsenate (PA, $\mathrm{KH}_{2} \mathrm{AsO}_{4}$ ) and an organic compound E-64 protease inhibitor (E-64; N-[N-(L-3-trans-carboxyoxirane-2carbonyl)-L-leucyl]-agmatine) were used as model compounds to test whether the diet is appropriate to be used in Tier-1 testing, as both compounds are known to be toxic to C. maculata from a previous study Duan et al. (2002) and our preliminary experiment (unpublished data). PA was purchased from SigmaAldrich (St. Louis, MO). E-64 was purchased from Roche Biochem (Indianopolis, IN). The nominal concentrations were $0,8,16$, and $32 \mu \mathrm{g} / \mathrm{g}$ dry weight of diet for testing PA and $0,50,150$, and $450 \mu \mathrm{g} / \mathrm{g}$ dry weight of diet for testing E-64. These rates were selected based on previous studies (Duan et al. 2005, 2007, 2008).

A primary stock solution of PA or E-64 was prepared with distilled water and incorporated into the diet between steps (iv) and (v) of the diet preparation using a dilution series to attain the target concentrations. The diet temperature was measured by a thermometer and when the temperature was $<50^{\circ} \mathrm{C}$, the test compounds were incorporated to minimize any possible degradation or deactivation. The other steps of diet preparation were the same as described above.

The experimental system and the provision of diets were the same as described above in the fitness bioassay, except the diets were replenished every $24 \mathrm{~h}$ to ensure the full activity of test compounds. Twenty- two insects were tested in each treatment, and the development, mortality, pupation rate, adult emergence rate, and the weight of adults was recorded. The larval weight was not measured in this assay because of limitations of the balance and small larval size after feeding on E-64, although it is a sensitive endpoint according to the results of the fitness bioassay. The bioassays were terminated when all insects had developed to adults or died in control treatments.

Data Analysis. The survival response of C. maculata to different dietary concentrations of PA or E-64 was analyzed using the Kaplan-Meier procedure and Logrank test. Frequency data (proportion of larvae developing to adults) were subjected to $\chi^{2}$ test. Data on development time ( $\mathrm{d}$ to pupae and $\mathrm{d}$ to adults) were analyzed by Kruskal-Wallis analysis of variance (ANOVA), and posthoc comparisons of mean ranks were made using Mann-Whitney $U$ test with Bonferroni correction, because the data did not satisfy the assumptions for parametric analysis. One-way ANOVA tests followed by Tukey honestly significant difference (HSD) were performed for the data of larval or adult weights because the data were normally distributed and variances were homogenous. All analyses were conduced with SPSS (version 13 for windows, 2004).

\section{Results}

Fitness of C. maculata Feeding on the Artificial Diets. All three diets met basic assay acceptability criteria (i.e., $>80 \%$ survival; Romeis et al. 2010). Over $95 \%$ of C. maculata larvae survived and developed to adults in diet 2 or diet 3 after $18 \mathrm{~d}$ feeding exposure (Table 2). No significant differences $(P>0.05)$ for the measured C. maculata life-table parameters were detected among the three diet treatments; however, the mean weight of 7 -d larvae fed diet 2 or diet 3 was statistically higher than those larvae fed $\operatorname{diet} 1(P<$ $0.001)$.

Assay With Potassium Arsenate. In the diet-only control treatment, $90 \%$ of C. maculata larvae survived and developed to adults after $18 \mathrm{~d}$ feeding exposure. With increasing concentrations of PA in diets, fewer larvae developed to adults, and only $22.7 \%$ larvae survived to adult stage in the diet containing the highest content of PA $(32 \mu \mathrm{g} / \mathrm{g}$ of diet) (Fig. 1). Survival analysis showed that there was statistically different 


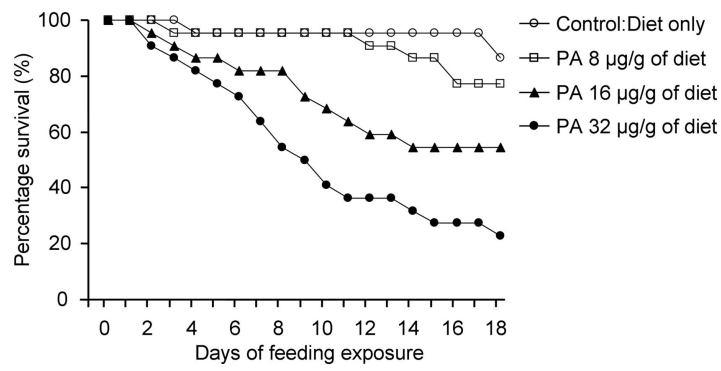

Fig. 1. Survival of C. maculata fed shrimp egg-based artificial diet containing different concentrations of potassium arsenate (PA). Twenty-two larvae (within $12 \mathrm{~h}$ ) were tested for each treatment.

amount the treatments $(P<0.0001)$. Pair-wise comparisons indicated that there was no significant difference $(P=0.61)$ in survival rate between the treatment containing PA at $8 \mu \mathrm{g} / \mathrm{g}$ diet and the control. In contrast, there were significantly decreased survival rates for the insects fed the diets containing $\mathrm{PA}$ at 16 and $32 \mu \mathrm{g} / \mathrm{g}$ compared with the control $(P=0.014$ and $P<0.0001$, respectively) (Fig. 1). Similarly, dosedependent responses were also found for the other life-table parameters of C. maculata when exposed to artificial diet containing different concentrations of PA (Table 3). The parameters of "days to pupation" and "days to adult emergence" appeared to be more sensitive than survival rate for detecting the effects of PA on C. maculata,based on statistically significant differences between the diet treatment with PA at 8 $\mu \mathrm{g} / \mathrm{g}$ and control (Mann-Whitney $U$ test, $P<0.001$ for both parameters).

Assay With E-64. Similar to the assays with PA, the survival rates of C. maculata also consistently decreased when they were fed diet with increased E-64 content (Fig. 2). Survival analysis showed that there were significant differences among the survival curves of different concentrations of E-64 $\left(\chi^{2}=45.36, \mathrm{df}=\right.$ $3, P<0.0001)$. The insects in E-64 treatments had significantly lower survival rates compared with those fed the control diet (for all, $P<0.0001$ ). Because no larvae reached the pupal stage, the development time of larvae to pupae and the adult weight could not be assessed.

Table 3. Life-table parameters (mean) of C. maculata fed shrimp egg-based artificial diet containing different concentrations of potassium arsenate

\begin{tabular}{lccc}
\hline \hline Treatment & $\begin{array}{c}\text { Days to } \\
\text { pupation } \\
( \pm \mathrm{SE})^{a}\end{array}$ & $\begin{array}{c}\text { Days to adult } \\
\text { emergence } \\
( \pm \mathrm{SE})^{a}\end{array}$ & $\begin{array}{c}\text { Newly emerged } \\
\text { adult mass } \\
(\mathrm{mg} \pm \mathrm{SE})^{b}\end{array}$ \\
\hline Control: diet only & $12.8 \pm 0.21 \mathrm{a}$ & $16.0 \pm 0.22 \mathrm{a}$ & $11.4 \pm 0.44 \mathrm{a}$ \\
PA $8 \mu \mathrm{g} / \mathrm{g}$ of diet & $14.7 \pm 0.17 \mathrm{~b}$ & $17.8 \pm 0.18 \mathrm{~b}$ & $10.1 \pm 0.39 \mathrm{ab}$ \\
PA $16 \mu \mathrm{g} / \mathrm{g}$ of diet & $15.8 \pm 0.27 \mathrm{c}$ & $19.0 \pm 0.21 \mathrm{c}$ & $9.0 \pm 0.39 \mathrm{~b}$ \\
PA 32 $\mu \mathrm{g} / \mathrm{g}$ of diet & $18.0 \pm 0.77 \mathrm{~d}$ & $20.5 \pm 0.50 \mathrm{c}$ & $8.43 \pm 0.80 \mathrm{~b}$ \\
\hline
\end{tabular}

Twenty-two insects were tested for each concentration treatment.

${ }^{a}$ Kruskal-Wallis ANOVA followed Mann-Whitney $U$ test.

${ }^{b}$ One-way ANOVA followed by Tukey HSD. Means followed by the same letter in the same column are not significantly different at the 0.05 error level.

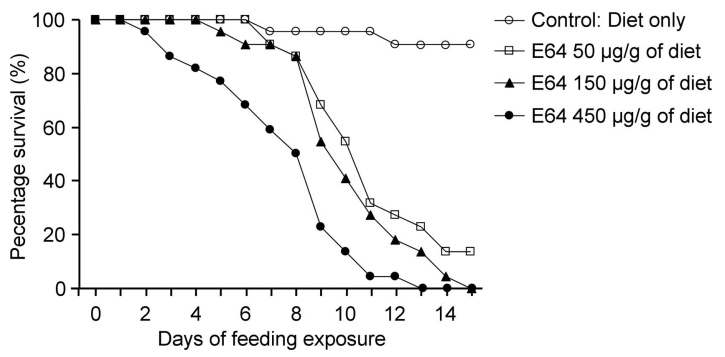

Fig. 2. Survival of C. maculata fed shrimp egg-based artificial diet containing different concentrations of E-64. Twenty-two larvae (within $12 \mathrm{~h}$ ) were tested for each treatment.

\section{Discussion}

Tier-1 testing under worst-case exposure conditions in the laboratory is useful and has traditionally been widely accepted by regulatory agencies and risk assessors a critical step for ecological assessment of conventional and biotechnology-derived plant-protection products (U.S. EPA 1998, Rose 2007; Romeis et al. 2008b, Dutton et al. 2003, Duan et al. 2010). In Tier-1 testing, the test species can be exposed to a much higher concentrations of test material compared with what it may encounter under field conditions. Thus, the results in those laboratory tests are more conservative than studies conducted under field conditions, and may better support the risk assessment because they provide robust data about the lack of toxicity of a test compound to a NTO (Duan et al. 2010; Raybould 2007; Romeis et al., 2010). In addition, Tier-1 laboratory testing also allows general conclusions about the susceptibility of the test species to the toxins independent of the test crop varieties, thus the data can be expanded to other GE crops expressing the same toxin (Romeis et al. 2006, Raybould and Quemada 2010).

Ideally a suitable artificial diet is available to establish a Tier-1 testing system for a given surrogate species. The diet should meet the following requirements: i) it should be readily accepted by the test species, and efficient for sustaining their normal survival and development; ii) the test compounds can be readily incorporated into the diet; and iii) the bioactivity of test substance should be maintained. In the current study, diet 1 served as the foundation for the other diets tested. Our fitness bioassay demonstrated all three diets were accepted by the test organisms, and larvae survived and completed development in an acceptable time period. Basic assay acceptability criteria were met by all three diets ( $>80 \%$ survival), with $>95 \%$ survival on diets 2 and 3. Although, 7-d larval weight was significantly higher in diets 2 and 3 no significant differences were detected for all other parameters, indicating the larvae developed normally. These results suggest that all three diets are acceptable, and thus meet the first requirement for establishment of a Tier-1 testing system. We chose to further test diet 2 in our bioassays because the diet is pourable before solidification, therefore it proved easier to incorporate our test compounds into the diet. 
When each test compound was mixed into the diet, the temperature of the mixture was controlled to be $<50^{\circ} \mathrm{C}$ measured by thermometer, a condition under which the test material should not be degraded and inactivated within a short time $(<2 \mathrm{~m})$ based on previous experience (Sivasupramaniam et al. 2008, Meissle and Romeis 2009). This meets the second requirement for assay development, as described. Additional experiments with enzyme-linked immunosorbent assays (ELISAs) and insect-sensitive bioassays confirmed the stability of a CrylAc protein when it was incorporated into the diet developed in this current study ( $\mathrm{Li}$ et al., unpublished data). Similarly, artificial diets have successfully been used to test the effects of purified arthropod-active proteins on a different arthropod predators including larvae of Aleochara bilineata (Gyllenhal) (Coleoptera: Staphylinidae) (Stacey et al. 2006), larvae of Poecilus chalcites (Say) (Coleoptera: Carabidae) (Duan et al. 2006), nymphs of Orius insidiosus (Say) (Heteroptera: Anthocoridae) (Stacey et al. 2006) and adult Chrysoperla carnea Stephens (Neuroptera: Chrysopidae) ( $\mathrm{Li}$ et al. 2008).

A successful Tier-1 testing system should efficiently measure the toxicity of the test compounds. We used the PA and E-64 to evaluate our system because they represent two important classes of compounds (PA is an inorganic chemical, while E-64 is an organic chemical). Additionally, PA has a broad spectrum of activity against many organisms including insect pests (Metcalf et al. 1962), and it has been used as a positive control in insect bioassays for risk assessments in previous studies (Duan et al. 2002, Duan et al. 2008, Álvarez-Alfageme et al. 2010). E-64 is a cysteine protease inhibitor specifically inhibiting papain and other cysteine proteases, as well as the serine protease tryp$\sin$, and has been used to characterize the digestive enzyme profile of a number of insects including coleopterans (Orr et al. 1994, Lončar et al. 2009). Previous studies showed that $\mathrm{E}-64$ has significant adverse effects on coleopteran predators (Leplé et al. 1995, Fabrick et al. 2002, Duan et al. 2005, Lončar et al. 2009). Although the toxicity of the two compounds to many insect species has been widely studied, its effect on C. maculata has not been evaluated to our knowledge.

In the dietary assays with PA and E-64, dose-dependent responses were found for survival of C. maculata. For both PA and E-64 dietary treatments, the survival rates were significantly lower at higher concentrations than at the lower concentrations (Fig. 1 and 2). Likewise, there were similar relationships found for other life table parameters ( $\mathrm{d}$ to pupation, $\mathrm{d}$ to adult emergence, and weight of newly emerged adult). The present data showed that the parameters of "d to pupation" and "d to adult emergence" are more sensitive compared with survival rate for detection of effects of PA on C. maculata. Therefore, the development duration may be an ideal measurement endpoint for assessing the impact of insecticidal compounds to this species. These results suggest that the test system was capable of detecting dietary effects of insecticidal substances on the survival and development of $C$. maculata.

C. maculata has been selected as a surrogate for assessing nontarget effects of IRGE crops because of the importance of coccinellids as natural enemies for controlling many kinds of insect pests in various crop systems, and the amenability of C. maculata in laboratory settings (Pilcher et al. 1997, Riddick et al. 1998, Duan et al. 2002, Lundgren et al. 2002). In previous studies, larvae or adults of C. maculata were generally exposed to Cry toxins by ingesting intoxicated prey (tri-trophic study) or plant tissue (Lundgren et al. 2004, Moser et al. 2008). Although these studies are valuable in assessing nontarget effects of $B t$ proteins expressed in plant tissues, they have limitations in their use for laboratory assessments on the potential hazard of insecticidal compounds produced by GE plants including: firstly because the test material is the GE plant tissue or the intoxicated prey, the insecticidal compounds concentrations cannot be adjusted, and thus there is no opportunity to develop a safety margin through concentration-response characterization (Romeis et al. 2006, 2010); secondly the effect of the insecticidal compounds of interest cannot be studied in isolation, i.e., we cannot rule out other differences between treatment and control; thirdly tri-trophic tests contain more variables and are often more complex than refined Tier-1 testing, and the results from these studies are more difficult to interpret (e.g., preyquality mediated effects may influence the results, Romeis et al. 2006); and fourthly such studies may underestimate the exposure level of the test species to insecticidal compounds under field conditions, and thus underestimate the potential risk of IRGE plants on the test species (Dutton et al. 2003, Garcia-Alonso et al. 2006, Romeis et al. 2006, 2010). In contrast, the Tier-1 laboratory testing system using artificial diet to expose the test insects to the insecticidal compound as developed here allow clear definition and manipulation of different dose levels needed for quantitative evaluation of potential toxicity of insecticidal products, such as Bt proteins, to the ladybird C. maculata.

In summary, an artificial diet using shrimp eggs was developed in the current study, and it was confirmed to be appropriate for use in Tier-1 testing system for assessing the potential hazard (or toxicity) effects after dietary exposure of insecticidal compounds produced by GE plants or conventional insecticides on the ladybird predator, C. maculata. Therefore the testing system presented here is not only valuable for assessing the potential impact of GE plants on C. maculata, but also providing an approach to evaluate the safety of a new gene product on the species before transformed to plant genome.

\section{Acknowledgments}

We thank Keri Carstens (Pioneer Hi-Bred International, Inc) for providing comments on earlier drafts of the manuscript. This study was supported by a postdoctoral grant to YL by the Swiss National Science Foundation (PBBEP3-125563) 
and the Chinese National Genetically Modified Organisms Breeding Major Projects (2008ZX08001-001).

\section{References Cited}

Álvarez-Alfageme, F., F. Bigler, and J. Romeis. 2010. Laboratory toxicity studies demonstrate no adverse effects of CrylAb and Cry3Bb1 to larvae of Adalia bipunctata (Coleoptera: Coccinellidae): the importance of study design. Transgen. Res. doi: 10.1007/s11248-010-9430-5.

Brookes, G., and P. Barfoot. 2010. GM crops: global socio-economic and environmental impacts 1996-2008, PG Economics Ltd, Dorchester, United Kingdom. (http://croplife. intraspin.com/Biotech/gm-crops-global-socio-economicand-environmental-impacts-1996-2008).

CAB International. 2007. CPC Report Coleomegilla maculata. Crop Protection Compendium, Wallingford, United Kingdom.

Duan, J. J., G. Head, M. J. McKee, T. E. Nickson, J. W. Martin, and F. S. Sayegh. 2002. Evaluation of dietary effects of transgenic corn pollen expressing Cry3Bb1 protein on a non-target ladybird beetle, Coleomegilla maculala. Entomol. Exp. Appl. 104: 271-280.

Duan, J. J., M. S. Paradise, J. G. Lundgren, and R. N. Wiedenmann. 2005. Genetically modified crops and ground beetles as non-target organisms: developing dietary toxicity assays for larvae of Poecilus chalcites (Coleoptera: Carabidae). Am. Entomol. 51: 227-230.

Duan, J. J., M. S. Paradise, J. G. Lundgren, J. T. Bookout, C. Jian, and R. N. Wiedenmann. 2006. Assessing non-target impacts of Bt corn resistant to corn rootworms: Tier-1 testing with larvae of Poecilus chalcites (Coleoptera: Carabidae). Environ. Entomol. 35: 135-142.

Duan, J. J., J. Huesing, and D. Teixeira. 2007. Development of tier-I toxicity assays for Orius insidiosus (Heteroptera: Anthocoridae) for assessing the risk of plant-incorporated protectants to nontarget heteropterans. Environ. Entomol. 36: 982-988.

Duan, J. J., D. Teixeira, J. E. Huesing, and C. Jiang. 2008. Assessing the risk to nontarget organisms from Bt corn resistant to corn rootworms (Coleoptera: Chrysomelidae): tier-I testing with Orius insidiosus (Heteroptera: Anthocoridae). Environ. Entomol. 37: 838-844.

Duan, J. J., J. G. Lundgren, S. Naranjo, and M. Marvier. 2010. Extrapolating non-target risk of Bt crops from laboratory to field. Biol. Lett. 6: 74-77.

Dutton, A., J. Romeis, and F. Bigler. 2003. Assessing the risks of insect resistant transgenic plants on entomophagous arthropods: Bt-maize expressing CrylAb as a case study. BioControl. 48: 611-636.

Fabrick, J., C. Behnke, T. Cazpla, K. Bala, A. G. Rao, K. J. Kramer, and G. R. Reeck. 2002. Effects of a potato cysteine proteinase inhibitor on midgut proteolytic enzyme activity and growth of the southern corn rootworm, Diabrotica undecimpunctata howardi (Coleoptera: Chrysomelidae). Insect Biochem. Mol. Biol. 32: 405-415.

Fitt, G. P. 2008. Have Bt crops led to changes in insecticide use patterns and impacted IPM? In J. Romeis, A. M. Shelton, and G. G. Kennedy, [eds.], Integration of insectresistant genetically modified crops within IPM programs. Springer Science + Business Media B.V. 303-328.

Garcia-Alonso, M., E. Jacobs, A. Raybould, T. E. Nickson, P. Sowig, H. Willekens, P. Van der Kouwe, R. Layton, F. Amijee, A. M. Fuentes, and F. Tencalla. 2006. A tiered system for assessing the risk of genetically modified plants to non-target organisms. Environ. Biosafety Res. 5: 57-65.
Hoffmann, M. P., and A. C. Frodsham. 1993. Natural enemies of vegetable insect pests. Cooperative Extension, Cornell University.

James, C. 2009. Global status of commercialized biotech/GM Crops: 2009. ISAAA Brief No. 39, International Service for the Acquisition of Agri-Biotech Applications, Ithaca, NY.

Kennedy, G. G. 2008. Integration of insect-resistant genetically modified crop within IPM programs. In J. Romeis, A. M. Shelton, and G. G. Kennedy, [eds.], Integration of insect-resistant genetically modified crops within IPM programs. Springer Science + Business Media B. V. pp $1-26$.

Leplé, J. C., M. Bonadé-Bottino, S. Augustin, G. Pilate, V. Dumanois Lê Tân, A. Delplanque, D. Cornu, and L. Jouanin. 1995. Toxicity to Chrysomela tremulae (Coleoptera: Chrysomelidae) of transgenic poplars expressing a cysteine proteinase inhibitor. Mol. Breed. 1: 319 328.

Li, Y., M. Meissle, and J. Romeis. 2008. Consumption of Bt maize pollen expressing Cry1Ab or Cry3Bb1 does not harm adult green Lacewings, Chrysoperla carnea (Neuroptera: Chrysopidae). PLoS One 3: e2909. doi:10.1371/ journal.pone.0002909.

Lončar, N., N. Božić, V. Nenadović, J. Ivanović, and Z. Vujčić. 2009. Characterization of trypsin-like enzyme from the midgut of Morimus funereus (Coleoptera: Cerambycidae) larvae. Arch. Biol. Sci. 64: 713-718.

Lundgren, J. G., and R. N. Wiedenmann. 2002. Coleopteran-specific Cry $3 \mathrm{Bb}$ toxin from transgenic corn pollen does not affect the fitness of a nontarget species, Coleomegilla maculata DeGeer (Coleoptera: Coccinellidae). Environ. Entomol. 31: 1213-1218.

Lundgren, J. G., and R. N. Wiedenmann. 2004. Nutritional suitability of corn pollen for the predator Coleomegilla maculata (Coleoptera: Coccinellidae). J. Insect Physiol. 50: 567-575.

Meissle, M., and J. Romeis. 2009. Insecticidal activity of $\mathrm{Cry} 3 \mathrm{Bbl}$ expressed in Bt maize on larvae of the Colorado potato beetle, Leptinotarsa decemlineata. Entomol. Exp. Appl. 131: 308-319.

Metcalf, C., W. Flint, and R. Metcalf. 1962. Destructive and useful insects: their habits and control. McGraw-Hill, New York.

Moser, S. E., J. D. Harwood, and J. J. Obrycki. 2008. Larval Feeding on Bt Hybrid and Non-Bt Corn Seedlings by Harmonia axyridis (Coleoptera: Coccinellidae) and $\mathrm{Co}$ leomegilla maculata (Coleoptera: Coccinellidae). Environ. Entomol. 37: 525-533.

[NAS] National Academy of Science. 2002. Environmental effects of transgenic plants: the scope and adequacy of regulation. Washington, DC: National Acad. Press. (http:// books.nap.edu/books/0309082633/html/index/html).

[OECD] Organisation for Economic Co-operation and Development. 2007. Consensus document on safety information on transgenic plants expressing Bacillus thuringiensis-derived insect control protein. Series on Harmonisation of Regulatory Oversight in Biotechnology, No. 42. Organisation for Economic Co-operation and Development, Paris. (http:/ /www. olis.oecd.org/olis/2007doc.nsf/LinkTo/NT00002DF6/ \$FILE/ JT03230592.PDF).

Orr, G. L., J. A. Strickland, and T. A. Walsh. 1994. Inhibition of Diabrotica larval growth by multicystatin from potato tubes. J. Insect. Physiol. 40: 893-900.

Pemberton, R. W., and N. J. Vandenberg. 1993. Extrafloral nectar feeding by ladybird beetles (Coleoptera; Coccinellidae). Proc. Entomol. Soc. Wash. 95: 139-151. 
Pilcher, C. D., J. J. Obrycki, M. E. Rice, and L. C. Lewis. 1997. Preimaginal development, survival and field abundance of insect predators on transgenic Bacillus thuringiensis corn. Environ. Entomol. 26: 446-454.

Pilcher, C. D., M. E. Rice, and J. J. Obrycki. 2005. Impact of transgenic Bacillus thuringiensis corn and crop phenology on five nontarget arthropods. Environ. Entomol. 34: 13021316.

Raybould, A. 2007. Environmental risk assessment of genetically modified crops: general principles and risks to nontarget organisms. BioAssay. 2: 8.

Raybould, A., and H. Quemada. 2010. Bt crops and food security in developing countries: realised benefits, sustainable use and lowering barriers to adoption. Food Sec. 2: 247-259.

Riddick, E. W., G. Dively, and P. Barbosa. 1998. Effect of a seed-mix deployment of Cry3A-transgenic and nontransgenic potato on the abundance of Lebia grandis (Coleoptera: Carabidae) and Coleomegilla maculata (Coleoptera: Coccinellidae). Ann. Entomol. Soc. Am. 91: 647653.

Romeis, J., M. Meissle, and F. Bigler. 2006. Transgenic crops expressing Bacillus thuringiensis toxins and biological control. Nat. Biotechnol. 24: 63-71.

Romeis, J., R. G. Van Driesche, B.I.P. Barratt, and F. Bigler. 2008a. Insect-resistant transgenic crops and biological control, pp 87-117. In Romeis, J., A. M. Shelton, and G. G. Kennedy, (eds.), Integration of insect-resistant genetically modified crops within IPM programs. Springer Science + Business Media B.V.

Romeis, J., D. Bartsch, F. Bigler, M. P. Candolfi, M. M. Gielkens, S. E. Hartley, R. L. Hellmich, J. E. Huesing, P. C. Jepson, R. Layton, et al. 2008b. Assessment of risk of insect-resistant transgenic crops to nontarget arthropods. Nat. Biotechnol. 26: 203-208.

Romeis, J., R. L. Hellmich, M. P. Candolfi, K. Carstens, A. De Schrijver, A.M.R. Gatehouse, R. A. Herman, J. E. Huesing, M. A. McLean, A. Raybould, et al. 2010. Recommendations for the design of laboratory studies on non-targetarthropods for risk assessment of genetically engineered plants. Trans. Res. doi:10.1007/s11248-010-9446-x.
Rong, J., Z. P. Song, T. J. de Jong, X. Zhang, S. Sun, X. Xu, H. Xia, B. Liu, and B. R. Lu. 2010. Modelling pollen-mediated gene flow in rice: risk assessment and management of transgene escape. Plant Biotech. J. 8: 1-13.

Rose, R. I. (ed.). 2007. White paper on tier-based testing for the effects of proteinaceous insecticidal plant-incorporated protectants on non-target invertebrates for regulatory risk assessment. U.S. Dep. Agric.-APHIS and US Environmental Protection Agency, Washington, DC. (http://www.epa. gov/pesticides/biopesticides/pips/non-target-arthropods. pdf).

Sivasupramaniam, S., W. J. Moar, L. G. Ruschke, J. A. Osborn, C. Jiang, J. L. Sebaugh, G. R. Brown, Z. W. Shappley, M. E. Oppenhuizen, J. W. Mullins, and J. T. Greenplate. 2008. Toxicity and characterization of cotton expressing Bacillus thuringiensis Cry1Ac and Cry2Ab2 proteins for control of lepidopteran pests. J. Econ. Entomol. 101: 546-554.

Snow, A. A., D. A. Andow, P. Gepts, E. M. Hallerman, A. Power, J. M. Tiedje, and L. L. Wolfenbarger. 2005. Genetically engineered organisms and the environment: current status and recommendations. Ecol. Appl. 15: 377 404.

Stacey, D., G. Graser, M. Mead-Briggs, and A. Raybould. 2006. Testing the impact on non-target organisms of insecticidal proteins expressed in transgenic crops. IOBC/ WPRS Bulletin 29: 171-179.

Tabashnik, B. E., G. C. Unnithan, L. Masson, D. W. Crowder, X. Li, and Y. Carriere. 2009. Asymmetrical cross-resistance between Bacillus thuringiensis toxins CrylAc and Cry2Ab in pink bollworm. Proc. Natl. Acad. Sci. U.S.A 106: 11889-11894.

[USEPA] U.S. Environmental Protection Agency. 1998. Guidelines for ecological risk assessment. U.S. Environmental Protection Agency, Risk Assessment Forum, Washington, DC.

Yao, K., N. Hu, W. Chen, R. Li, Q. Yuan, F. Wang, Q. Qian, and S. Jia. 2008. Establishment of a rice transgene flow model for predicting maximum distances of gene flow in southern China. New Phytol. 180: 217-228.

Received 28 September 2010; accepted 6 January 2011. 